\title{
Nutrient distribution on soil and aboveground biomass of Macaranga gigantea five years after planting
}

\author{
DWI SUSANTO ${ }^{1, \bullet}$, RATNA KUSUMA $^{1}$, RUDIANTO AMIRTA $^{2}$ \\ ${ }^{1}$ Department of Biology, Faculty of Mathematics and Natural Sciences, Mulawarman University. Jl. Barong Tongkok No. 4, Gunung Kelua, \\ Samarinda Ulu, Samarinda-75123, East Kalimantan, Indonesia. Tel./fax.: +62-541-749140, 749152, 749153, "email: susantodwiki@ yahoo.com \\ ${ }^{2}$ Faculty of Forestry, Mulawarman University. Jl. Ki Hajar Dewantara, Kampus Gunung Kelua, Samarinda 75123, East Kalimantan, Indonesia
}

Manuscript received: 27 September 2017. Revision accepted: 2 April 2018.

\begin{abstract}
Susanto D, Kusuma R, Amirta R. 2018. Nutrient distribution on soil and aboveground biomass of Macaranga gigantea five years after planting. Asian J For 2: 12-19. Despite the high potentials of Macaranga gigantea to be developed as biofuel plantation, there is limited understanding of the growth of this species especially when it is planted as uniform stand and treated with silvicultural application. This research aimed to investigate the growth and accumulation of aboveground biomass of $M$. gigantea in varying fertilization treatments five years after planting, and to evaluate the distribution of nutrients in soil and aboveground biomass. Five treatments at randomized design were established with each treatment having three blocks, and each block contained 20 plants, making 300 plants in total. The five treatments of $M$. gigantea were the application of NPK fertilizer at five measures, i.e.: P0: $0 \mathrm{~g}, \mathrm{P} 1: 40 \mathrm{~g}, \mathrm{P} 2$ : $80 \mathrm{~g}, \mathrm{P} 3: 120 \mathrm{~g}$ and P4: $160 \mathrm{~g}$. Aboveground biomass and nutrient contents of N, P, K, Ca and Mg accumulated the plants were measured across the treatments, while soil sampling was conducted to analyze the nutrients accumulated in the soil. The research findings revealed that treatment $\mathrm{P} 4$ had the best growth performance with accumulation of $\mathrm{N}, \mathrm{P}, \mathrm{K}, \mathrm{Ca}$ and Mg in wood, bark, branches, and leaves twice as higher than those in treatment P0. The most distributed nutrients in the soil were magnesium, nitrogen, calcium, and phosphorus. Whereas the most accumulated nutrient in plant was potassium. The relative portion of $\mathrm{K}$ stored in the soil is quite small (44.18\%) while $\mathrm{K}$ accumulated in plant was $55.82 \%$. These findings imply that if $M$. gigantea plantation is harvested at five years rotation, it needs to give attention to the availability of potassium nutrients for the next planting cycles.
\end{abstract}

Keywords: Biomass, Macaranga gigantea, distribution nutrient, soil

\section{INTRODUCTION}

Macaranga gigantea is a pioneer and fast-growing tree species widely distributed in lowland of tropical rainforest, usually growing within the gaps after shifting cultivation (Susanto et al. 2016b), forest fires (Silk 2008) and timber harvestings (Susanto et al. 2017a). The plant reproduces by forming flower buds initiated in the dry season and the fruits ripened in the rainy season (Bentos et al. 2008).

Because of the rapid growth and high accumulation of biomass, M. gigantea has the potentials to be developed as raw source for bioethanol by establishing large-scale plantation forestry (Amirta et al. 2016). So far, only limited number of tree species have been developed as biofuel in the tropical region with several of them are recognized as non-native species. The hindrance of such development is mainly due to the limited understanding of the early growth of $M$. gigantea especially when it is planted as uniform stand compared to when it grows naturally. The lack of knowledge is particularly eminent from the seedling development stage into juvenile age.

The seeds of $M$. gigantea are classified as orthodox seeds and have low water content. The seeds that fell under the tree are germinating in approximately 24 days (Susanto et al. 2016a). Susanto et al. (2016a) reported that wet extraction without fruit drying treatment is able to increase seeds germination to $65 \%$ ) with germination time first seeds (GTFS) $7.67 \pm 1.15$ days, germination time last seeds
(GTLS) $17.33 \pm 4.04$, and mean germination times (MGT) $11.97 \pm 1.93$ days. However, previous studies demonstrated that additional seed treatments do not necessarily increase germination rate. Using dry seed extraction treatment, the seeds produce low seed germination rate of 2-10\% (Suita and Nurhasiby 2009), while soaking the seeds into $0.2 \%$ potassium nitrate solution for 20 minutes before germinating on sand medium is only able to increase seed germination rates up to $20 \%$ (Mindawati et al. 2010). During the germination stage, $M$. gigantea seedlings showed the highest relative growth rate when planted on mushroom spawn waste media, followed by compost, topsoil, and sand media (Susanto et al. 2016a).

The experimental planting of $M$. gigantea seedlings in the field also showed mixed results. Lawrence (2001) reported that the seedlings of $M$. gigantea grew rapidly over the first of 18 weeks when planted in polybags enough supplied with a combination of nitrogen and phosphorus fertilizers. While, Nussbaum et al. (1995) found that nutritional deficiency is an important factor that inhibits early growth $M$. gigantea at the age 6 months after planting in degraded land of unused log piles in Malaysia.

Susanto et al. (2016b) reported that in secondary forests after shifting cultivation, M. gigantea plants accumulated phosphorus and potassium nutrient mostly in the leaves. On the other hand, in secondary forests after selective logging, most accumulated nutrients in M. gigantea were potassium, calcium, and magnesium. It suggested that bases nutrients, 
potassium, calcium, and magnesium are by $M$. gigantea and extremely important to its growth (Susanto et al. 2017a). In monoculture system, M. gigantea was fertilized with NPK at the age of 1 year, the most nutrient element accumulated were potassium, followed by phosphorus and then nitrogen (Susanto et al. 2017b).

There is a lack information about aboveground biomass of $M$. gigantea treated with silvicultural application in relation to nutrient content stored in the soil. This research aimed to investigate the growth and accumulation of aboveground biomass of $M$. gigantea in varying fertilization treatments five years after planting, and to evaluate the distribution of nutrients in soil and aboveground biomass. This information is very important as reference for the development of $M$. gigantea plantation.

\section{MATERIALS AND METHODS}

\section{Experimental site description}

This research was conducted at the research forest of Faculty of Forestry, Mulawarman University, Samarinda, East Kalimantan, Indonesia (000.44.71,11" South and $1170.21 ; 67,50 "$ East). The experimental plot had an extent of $0.7 \mathrm{ha}$, consisting planting trial of $M$. gigantea at the age of 5 years old. The trial was set up with five randomized treatments plots, each treatment had three blocks, and each block contained 20 plants, making $20 \times 5 \times 3=300$ plants in total. The five treatments of $M$. gigantea were the application of NPK fertilizer at five measures, i.e.: P0: $0 \mathrm{~g}, \mathrm{P} 1: 40 \mathrm{~g}$,
P2: 80 g, P3: 120 g and P4: 160 g. Fertilization was conducted two times, i.e., directly after planting and 6 months after planting. Weed cleaning was done once for 4 months until the plant age was 2 years old (Susanto et al. 2017b).

\section{Procedures}

Plant measurement and soil analysis

The samples of the five-year-old $M$. gigantea were observed through direct measurement. The stem heights, diameter, height increment and diameter increment were the parameters in this research. For soil analysis, soil samples were taken at a depth of $0-30 \mathrm{~cm}$ and $30-60 \mathrm{~cm}$ at each plot. Soil analysis was conducted after the samples were oven-dried with a temperature of $150^{\circ} \mathrm{C}$ until the weight was constant. Composite sample was wind-dried and its total Nitrogen (Kjeldahl), available phosphorus (Bray), available potassium, calcium, and magnesium were analyzed (Susanto et al. 2017b).

\section{Measuring Macaranga gigantea biomass}

Biomass measurements were limited only to aboveground biomass of the average tree after stratification method. The determination of strata boundaries for sample selection was performed using cumulative method. The trees sampled from one plot were selected after all the available trees were grouped into three stages based on their estimated size according to the formula $\mathrm{D}^{2} \mathrm{H}$ (diameter squared multiplied by height).

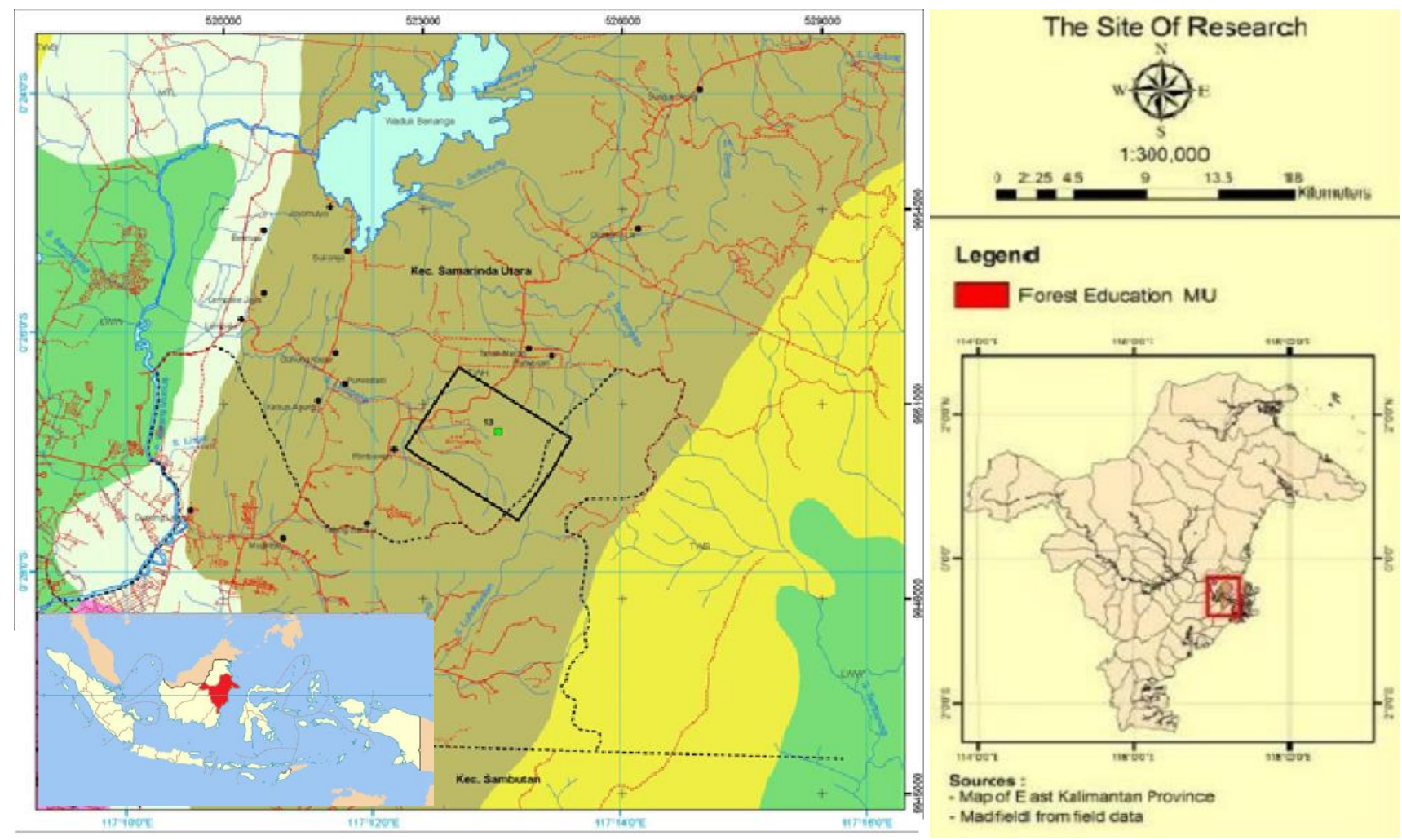

Figure 1. Map of the experimental site in the research forest of Faculty of Forestry, Mulawarman University, Samarinda, East Kalimantan, Indonesia 
The entire stand biomass was calculated by multiplying the dry weight of the components of the sampled tree by the number of trees in each stage, and then it was converted into a biomass per hectare. The wet weight of every component including wood, barks, branch, and leaves was measured according to Ruhiyat (1996) methods. Samples of the wood, barks, branch, and leaves were weighed in wet and dry condition. The plant samples were taken to the laboratory and their nutrient contents $(\mathrm{N}, \mathrm{P}, \mathrm{K}, \mathrm{Ca}, \mathrm{Mg})$ were analyzed.

\section{Measuring nutrients in plant}

The total $\mathrm{N}$ concentration was measured using Kjeldahl method (extraction, distillation, titration). To measure element of $\mathrm{P}$ and $\mathrm{K}$, the plant components were extracted using High-Pressure Digestion method at the temperature of $180^{\circ} \mathrm{C}$ for 10 hours with $\mathrm{HNO} 3$ as a reductant. Phosphorus was measured by calorimetric technique using nitrate-molybdate-vanadate acid as a coloring agent, and was measured using spectrophotometer at the wavelength of $470 \mathrm{~nm}$. Potassium, calcium, and magnesium were measured using Atomic Absorption Spectrophotometer at the wavelength of $766.5 \mathrm{~nm}, 489.5 \mathrm{~nm}$, and $245.2 \mathrm{~nm}$. To calculate macronutrient elements $(\mathrm{N}, \mathrm{P}, \mathrm{K}, \mathrm{Ca}, \mathrm{Mg})$ that were accumulated in the three components in the stand, the dry weight of the tree component was multiplied by its nutrient concentration (Susanto et al. 2017b).

\section{Data analysis}

Nutrient distribution in soil and in the $M$. gigantea plants at the five-year-old was observed. The content of macronutrients $(\mathrm{N}, \mathrm{P}, \mathrm{K}, \mathrm{Ca}, \mathrm{Mg}$ ) in the plant parts were calculated by multiplying the dry weight of the part with nutrient concentration. Based on the nutrients stored in the soil and the nutrient accumulated in the $M$. gigantea stands, it can be obtained information about the number of nutrients stored in the soil (kg.ha-1) and its relative portion (\%) accumulated in the plant.

\section{RESULTS AND DISCUSSION}

\section{Plant growth}

At the age of 5 years, the best growth of $M$. gigantea is shown by the treatment P4 with mean stem diameter of $12.88 \pm 4.2 \mathrm{~cm}$, stem height of $10.25 \pm 2,9 \mathrm{~m}$, increment diameter $2.58 \mathrm{~cm} . \mathrm{y}^{-1}$ and hight increment $2.05 \mathrm{~m} . \mathrm{y}^{-1}$ (Figure 2).

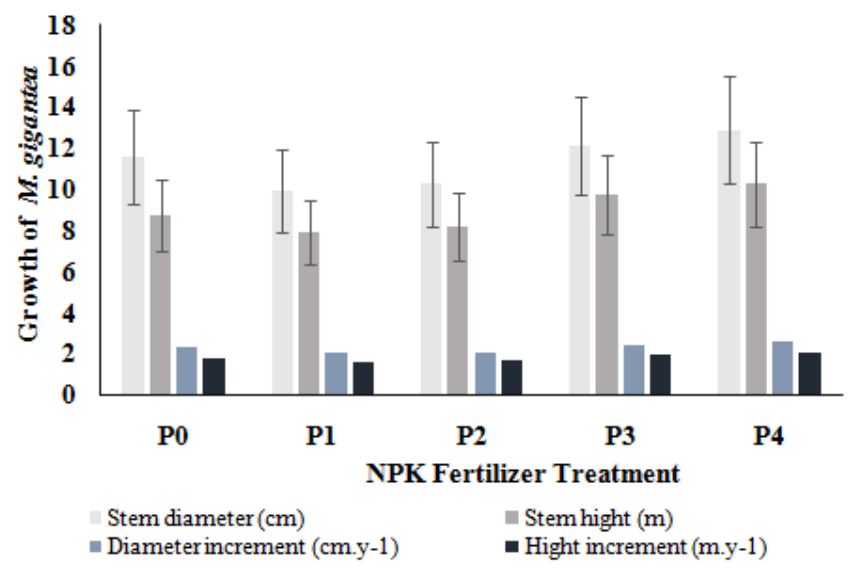

Figure 2. The growth parameters of Macaranga gigantea across five different treatments at the age of five years old.

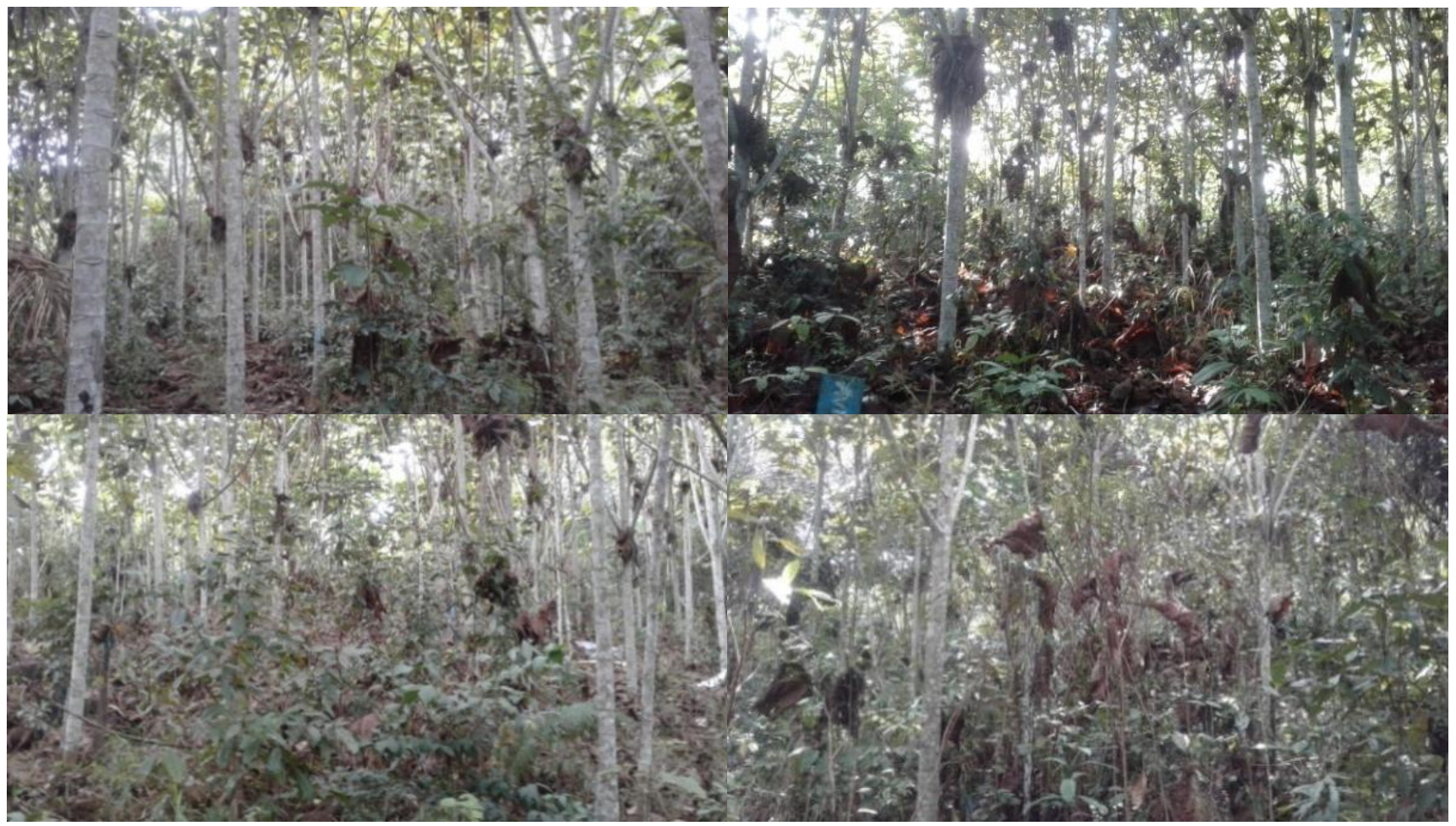

Figure 3. The stand of Macaranga gigantea plants at planting plots at the age of five years 


\section{Plant biomass}

The result on aboveground biomass estimation of $M$. gigantea showed that the highest biomass was produced by treatment P4 with 64.51 ton.ha $^{-1}$, comprising 27.58 tons stored in main stem, 5.078 tons in bark, 22.938 tons in branch (wood and bark), and 8.914 tons in leaves. Woody biomass had the largest biomass component with 50.52 ton.ha ${ }^{-1}$, consisting of 27.58 tons stored in the stem and 22.938 tons in the branches. The lowest biomass was produced by treatment P0 with 25.039 ton.ha ${ }^{-1}$. Based on this result, it can be concluded that fertilization of $160 \mathrm{~g}$ per plant (P4) increases biomass production by 250 percent.

\section{Nutrient content in plant components}

Potassium was the most accumulated nutrient in the five-year-old stands, followed by nitrogen, calcium, phosphorus, and magnesium. The amount of nutrients absorbed by $M$. gigantea stands were potassium, ranged from 239.88 to $676.20 \mathrm{~kg} \cdot \mathrm{ha}^{-1}$ with an average of 413.50 kg.ha-1 ${ }^{-1}$ calcium, ranged from 66.51 to $114.56 \mathrm{~kg} . \mathrm{ha}^{-1}$ with an average of $232.62 \mathrm{~kg} \cdot \mathrm{ha}^{-1}$; nitrogen, ranged from 155.91 to $344.00 \mathrm{~kg} . \mathrm{ha}^{-1}$ with an average of $232.62 \mathrm{~kg} \cdot \mathrm{ha}^{-1}$; and

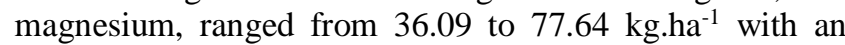
average of $51.93 \mathrm{~kg} \cdot \mathrm{ha}^{-1}$. The highest concentration of nitrogen, phosphorus, potassium, calcium and magnesium occurred at treatment P4 with fertilization of NPK at $160 \mathrm{~g}$ per tree (Table.1).

\section{Soil nutrient content}

Soil nutrient concentration at treatment plot varied in value. There is an increasing tendency of dosage of NPK fertilizer to decrease soil nutrient concentration at each treatment plot. In terms of $\mathrm{N}$, the highest concentration at the depth of $0-60 \mathrm{~cm}$ was at the P2 plot with $13405.4 \mathrm{~kg} . \mathrm{ha}$ ${ }^{1}$, followed by the P1 plot with $12744.5 \mathrm{~kg} \cdot \mathrm{ha}^{-1}$, P3 plot with $12210.7 \mathrm{~kg} \cdot \mathrm{ha}^{-1}$, plot P0 with $12136.5 \mathrm{~kg} \cdot \mathrm{ha}^{-1}$ and the lowest was at plot P4 with $10888.7 \mathrm{~kg} \cdot \mathrm{ha}^{-1}$. In terms of P, the highest concentration at the depth of $0-60 \mathrm{~cm}$ was at the plot P0 with $441.3 \mathrm{~kg} \cdot \mathrm{ha}^{-1}$, followed by plot P1 with 435.4 kg.ha-1, plot P2 with $386.5 \mathrm{~kg}$. ha ${ }^{-1}$, plot P4 with 377.4 kg.ha ${ }^{-1}$ and the lowest was at plot P3 with $291.8 \mathrm{~kg}^{-h^{-1}}$. The highest $\mathrm{K}$ nutrient occurred at plot P0 with 1034.2 $\mathrm{kg} \cdot \mathrm{ha}^{-1}$, followed by plot P2 with $603.7 \mathrm{~kg} \cdot \mathrm{ha}^{-1}$, plot P1 with $573.9 \mathrm{~kg} \cdot \mathrm{ha}^{-1}$, plot P4 with $535.2 \mathrm{~kg} \cdot \mathrm{ha}^{-1}$ and the lowest was at plot P3 with $448.8 \mathrm{~kg} \cdot \mathrm{ha}^{-1}$. The highest Ca occurred at plot P0 with $26953 \mathrm{~kg} \cdot \mathrm{ha}^{-1}$, followed by plot P1 with $26232 \mathrm{~kg} \cdot \mathrm{ha}^{-1}$, plot P3 with $25085 \mathrm{~kg} \cdot \mathrm{ha}^{-1}$, plot P2 with $23630 \mathrm{~kg}$. ha ${ }^{-1}$ and the lowest was at plot P4 with $21963 \mathrm{~kg} \cdot \mathrm{ha}^{-1}$. While the concentration of $\mathrm{Mg}$ was the highest at plot P0 with $51292 \mathrm{~kg} \mathrm{ha}^{-1}$, followed by plot P1 with $48111 \mathrm{~kg} \cdot \mathrm{ha}^{-1}$, plot P2 with $45603 \mathrm{~kg} \cdot \mathrm{ha}^{-1}$, plot P3 with $39800 \mathrm{~kg} \cdot \mathrm{ha}^{-1}$ and the lowest was at plot P4 with $38520 \mathrm{~kg} \cdot \mathrm{ha}^{-1}$.

The nutrient content in $M$. gigantea is positively correlated with biomass production at 5 years of age. The higher the nutrient content of biomass the higher the biomass production (Figure 5). On the other hand, the relationship between soil nutrient content and biomass production shows negative correlation, i.e., the higher the biomass production, the lower nutrient content in the soil
(Figure 6). The same is also shown in the relationship between soil nutrient and nutrient content in plant (Figure 7).

\section{Nutrients stored in the soil and nutrients accumulated in aboveground biomass}

The nutrient content stored in the soil and nutrients accumulated in $M$. gigantea is shown in Figure 8.

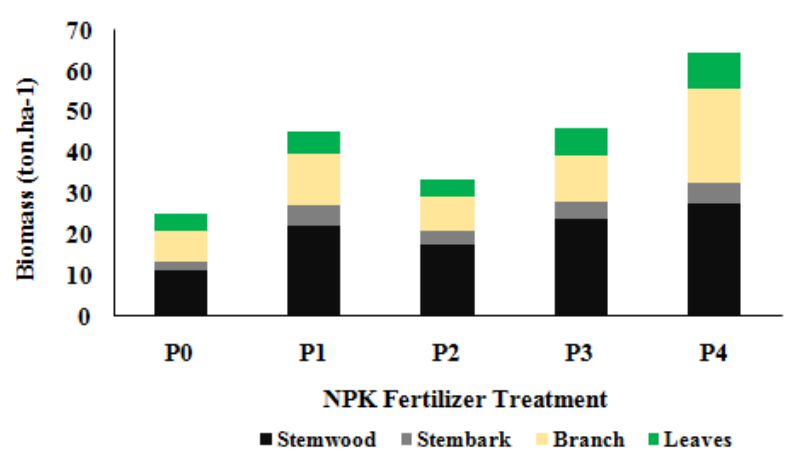

Figure 4. The distribution of aboveground biomass stored in plant components in Macaranga gigantea (five-year-old) across five different treatments.

Table 1. Nutrient content stored in plant components in Macaranga gigantea (five-year-old) across five different treatments

\begin{tabular}{|c|c|c|c|c|c|c|}
\hline \multirow{2}{*}{$\begin{array}{c}\text { Nutri- } \\
\text { ents }\end{array}$} & \multirow{2}{*}{$\begin{array}{c}\text { Fertilizer } \\
\text { appli- } \\
\text { cation }\end{array}$} & \multicolumn{5}{|c|}{$\begin{array}{c}\text { Nutrient content of plant components } \\
\left(\mathrm{kg}^{\left.-h^{-1}\right)}\right)\end{array}$} \\
\hline & & $\begin{array}{l}\text { Stem } \\
\text { wood }\end{array}$ & $\begin{array}{l}\text { Stem } \\
\text { bark }\end{array}$ & Branch & Leaf & Total \\
\hline \multirow[t]{5}{*}{$\mathrm{N}$} & P0 & 39.48 & 13.16 & 33.81 & 69.48 & 155.92 \\
\hline & $\mathrm{P} 1$ & 63.59 & 24.18 & 44.05 & 91.74 & 223.56 \\
\hline & $\mathrm{P} 2$ & 48.75 & 21.40 & 35.50 & 70.69 & 176.34 \\
\hline & P3 & 65.28 & 23.92 & 53.96 & 120.13 & 263.29 \\
\hline & P4 & 79.16 & 24.74 & 9.54 & & 344.01 \\
\hline Mean & & 59.25 & 21.48 & 51.37 & & 232.63 \\
\hline \multirow[t]{5}{*}{$\mathrm{P}$} & P0 & 6.08 & & 7.07 & & 20.91 \\
\hline & $\mathrm{P} 1$ & 4.94 & & 3.35 & & 17.79 \\
\hline & $\mathrm{P} 2$ & 2.16 & 35 & 5.79 & 6.95 & 16.23 \\
\hline & P3 & 3.47 & 1.99 & 8.52 & 8.53 & 22.52 \\
\hline & P4 & 11.72 & 3.14 & 14.79 & 13.39 & 43.04 \\
\hline Mean & & 5.67 & 1.82 & 7.90 & 8.70 & 24.10 \\
\hline \multirow[t]{5}{*}{ K } & P0 & 69.86 & 28.80 & 66.17 & 75.06 & 239.89 \\
\hline & P1 & 165.96 & 32.47 & 104.23 & 97.07 & 399.72 \\
\hline & P2 & 57.04 & 40.48 & 104.65 & 86.63 & 288.79 \\
\hline & P3 & 144.57 & 49.58 & 145.97 & 122.81 & 462.93 \\
\hline & P4 & 198.95 & 66.95 & 240.08 & 170.23 & 676.20 \\
\hline Mean & & 127.28 & 43.66 & 132.22 & 110.36 & 413.51 \\
\hline \multirow[t]{5}{*}{$\mathrm{Ca}$} & P0 & 27.08 & 13.12 & 14.20 & 12.11 & 66.51 \\
\hline & $\mathrm{P} 1$ & 11.78 & 28.02 & 20.97 & 15.06 & 75.83 \\
\hline & $\mathrm{P} 2$ & 22.36 & 16.85 & 11.27 & 13.07 & 63.55 \\
\hline & P3 & 14.91 & 24.21 & 20.94 & 16.59 & 76.65 \\
\hline & P4 & 30.47 & 17.87 & 40.16 & 26.07 & 114.57 \\
\hline Mean & & 21.32 & 20.01 & 21.51 & 16.58 & 79.42 \\
\hline \multirow[t]{5}{*}{$\mathrm{Mg}$} & P0 & 14.46 & 4.50 & 8.318 & 8.82 & 36.10 \\
\hline & $\mathrm{P} 1$ & 18.99 & 11.47 & 12.66 & 12.57 & 55.69 \\
\hline & $\mathrm{P} 2$ & 16.44 & 6.81 & 10.79 & 10.52 & 44.55 \\
\hline & P3 & 13.97 & 6.82 & 11.18 & 13.72 & 45.69 \\
\hline & $\mathrm{P} 4$ & 25.17 & 8.49 & 25.80 & 18.19 & 77.64 \\
\hline Mean & & 17.81 & 7.62 & 13.75 & 12.76 & 51.93 \\
\hline
\end{tabular}

Note: $\mathrm{P} 0=$ control without fertilizer, $\mathrm{P} 1=$ NPK fertilizer $40 \mathrm{~g}, \mathrm{P} 2$ $=$ NPK fertilizer $80 \mathrm{~g}, \mathrm{P} 3=\mathrm{NPK}$ fertilizer $120 \mathrm{~g}$ and P4 $=$ NPK fertilizer $160 \mathrm{~g}$. 

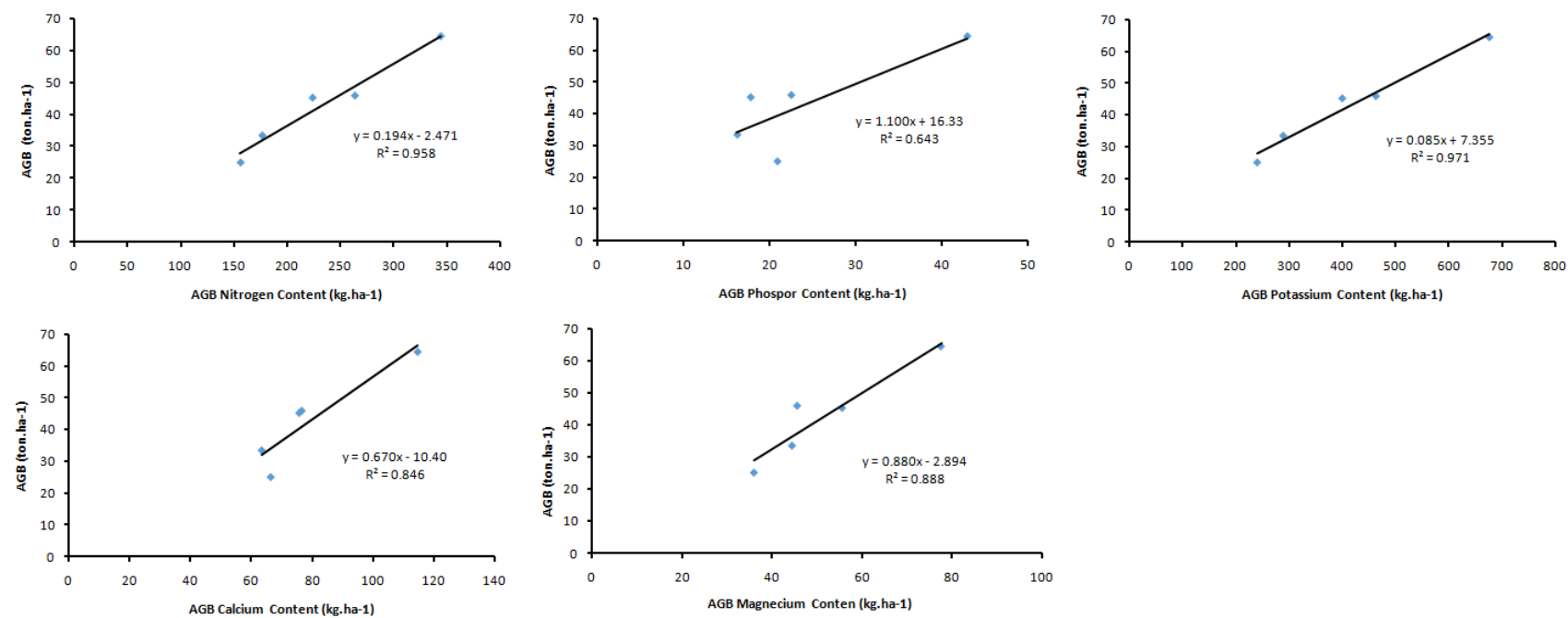

Figure 5. Corelation between aboveground biomassa and nutrient content stored in the plant of Macaranga gigantea at five years old
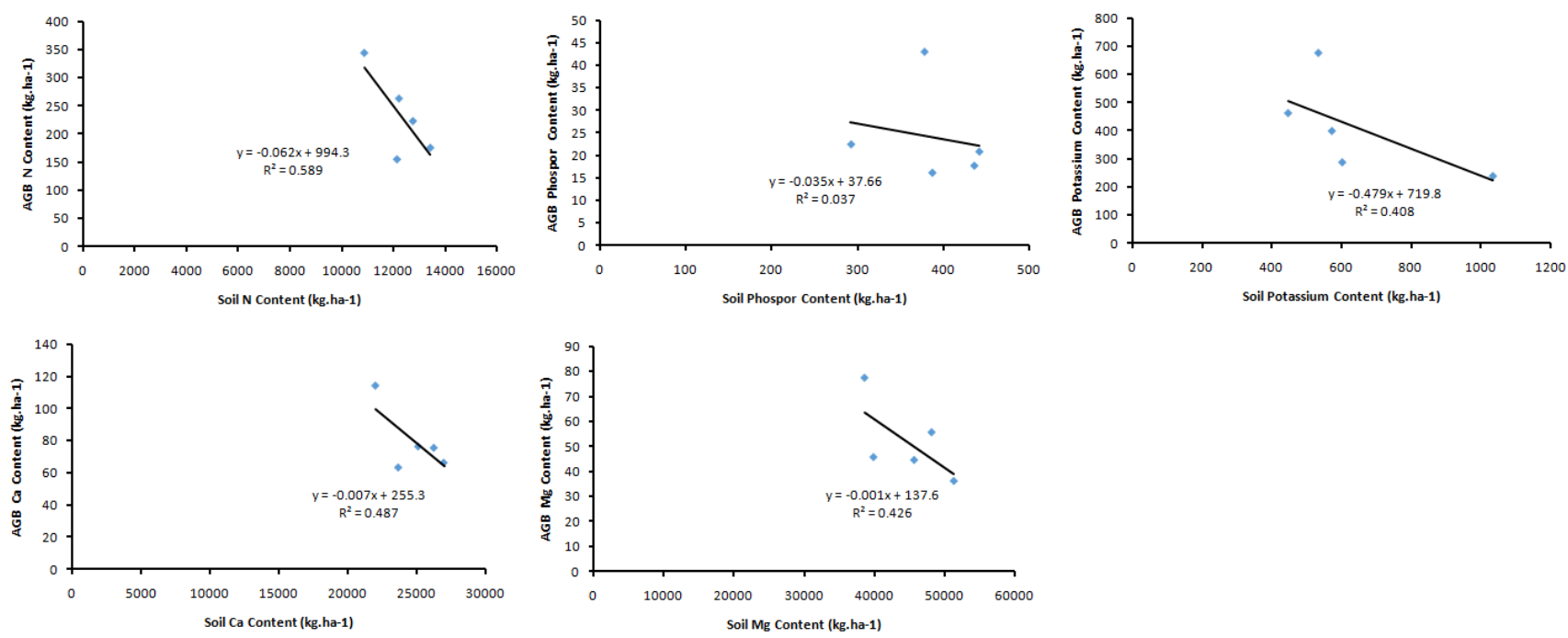

Figure 6. Corelation between soil nutrient and plant nutrient content of Macaranga gigantea at five years old
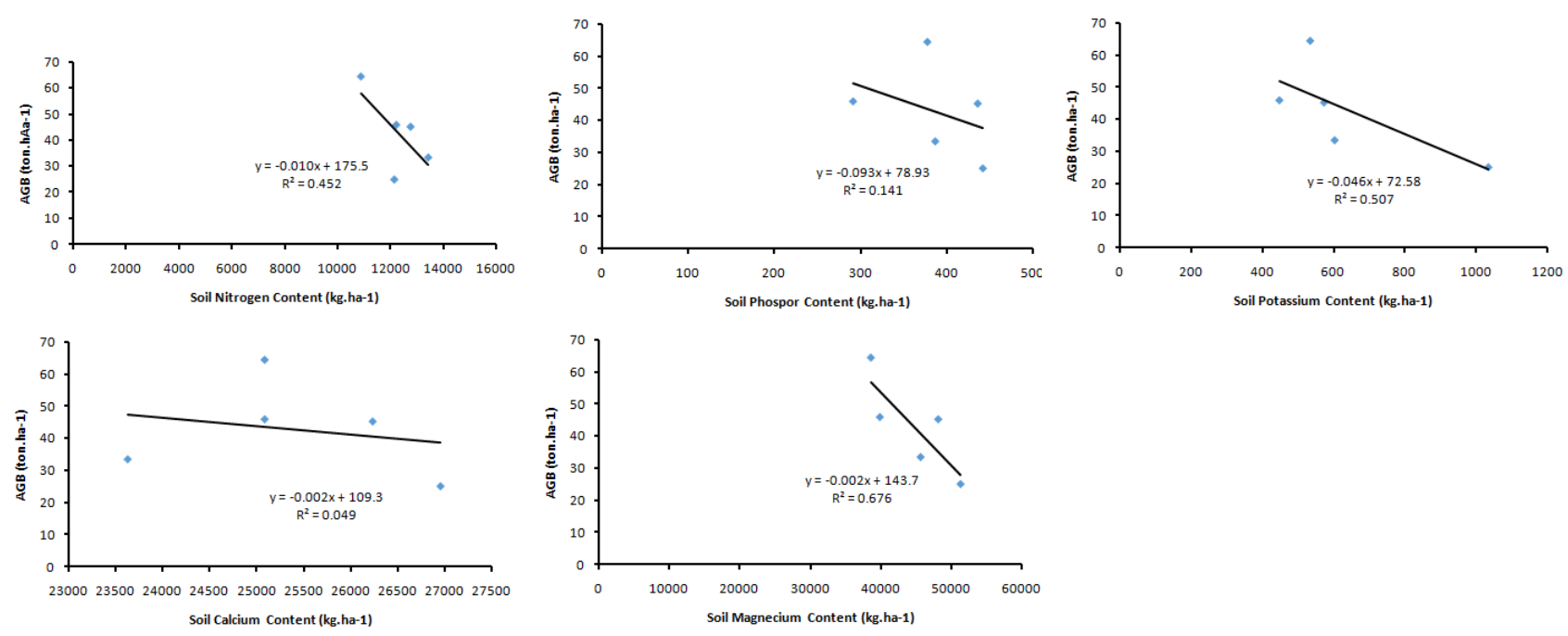

Figure 7. Corelation between soil nutrient content and aboveground biomass of Macaranga gigantea at five years old 


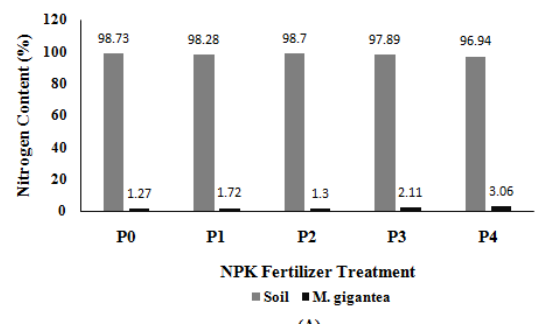

(A)

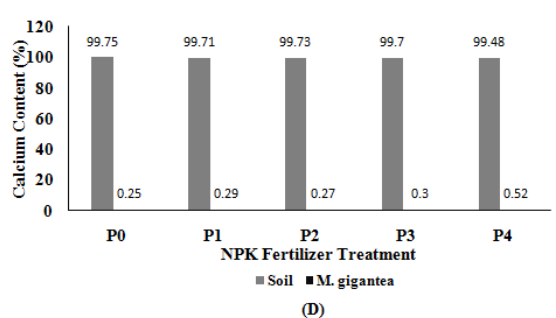

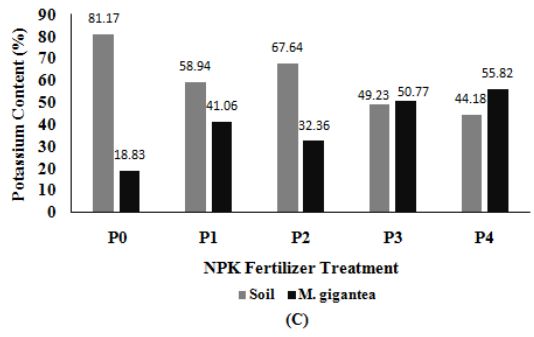

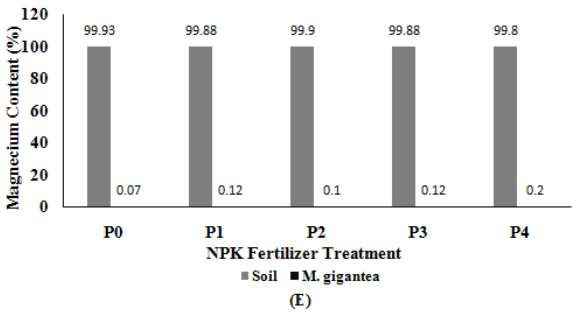

Figure 8. The proportion of nutrients stored in the soil and nutrient accumulated in Macaranga gigantea plants at five years old.

Table 2. Soil nutrient contents in Macaranga gigantea plant at the age of five years

\begin{tabular}{ccccccc}
\hline Fertilizer & Soil & \multicolumn{5}{c}{ Soil nutrient content (kg.ha' } \\
\cline { 3 - 7 } application & depth & N & P & K & Ca & Mg \\
\hline \multirow{6}{*}{} & & & & & & \\
& $30-60$ & 5385.7 & 290.7 & 705.9 & 10159 & 24100 \\
P1 & $0-60$ & 12136.5 & 441.3 & 1034.2 & 26953 & 51292 \\
& $0-30$ & 6561.9 & 191.8 & 280.8 & 8710 & 24068 \\
& $30-60$ & 6182.6 & 243.7 & 293.1 & 17522 & 24043 \\
P2 & $0-60$ & 12744.5 & 435.4 & 573.9 & 26232 & 48111 \\
& $0-30$ & 7667.8 & 140.9 & 373.1 & 15770 & 22234 \\
& $30-60$ & 5737.6 & 245.6 & 230.6 & 7860 & 23369 \\
P3 & $0-60$ & 13405.4 & 386.5 & 603.7 & 23630 & 45603 \\
& $0-30$ & 6867.9 & 96.9 & 239.4 & 11872 & 18774 \\
& $30-60$ & 5342.8 & 195.0 & 209.5 & 13213 & 21026 \\
P4 & $0-60$ & 12210.7 & 291.8 & 448.8 & 25085 & 39800 \\
& $0-30$ & 6045.9 & 153.8 & 281.5 & 12169 & 21444 \\
& $30-60$ & 4842.8 & 223.6 & 253.7 & 9794 & 17076 \\
& $0-60$ & 10888.7 & 377.4 & 535.2 & 21963 & 38520 \\
\hline
\end{tabular}

Note: P0 = control without fertilizer, P1 = NPK fertilizer $40 \mathrm{~g}, \mathrm{P} 2$ $=$ NPK $80 \mathrm{~g}$ fertilizer, $\mathrm{P} 3=$ NPK fertilizer $120 \mathrm{~g}$ and P4 $=$ NPK $160 \mathrm{~g}$ fertilizer.

The relative portion of $\mathrm{N}, \mathrm{P}, \mathrm{Ca}$, and $\mathrm{Mg}$ nutrients stored in the soil was still very large, ranging from 89.76 to $99.93 \%$, whereas that accumulating in $M$. gigantea stands was very small at $0.20 \%-10.24 \%$. It means that the absorbed nutrients of $\mathrm{N}, \mathrm{P}, \mathrm{Ca}$, and $\mathrm{Mg}$ by $\mathrm{M}$. gigantea were relatively small. On the other hand, the relative portion of accumulated $\mathrm{K}$ nutrients in the soil was quite small, ranging from 44.18 to $81.17 \%$, while that in $M$. gigantea stands was large enough, ranging between 18.83 and $55.82 \%$. It means that $\mathrm{K}$ was highly absorbed from the soil and was accumulated in $M$. gigantea plant tissue, followed by phosphorus, nitrogen, calcium, and magnesium (Figure 8).

\section{Discussion}

At the age of five years, the best growth of $M$. gigantea was found in P4 plot which was treated with NPK fertilizer at $160 \mathrm{~g}$ dosage (Figure 1). The same result was also found in aboveground biomass accumulation (Figure 3). In contrast to Susanto et al. (2017b) which found that at the age of one year the best growth and production of aboveground biomass were found in the application of NPK fertilizer with the dosage of $120 \mathrm{~g}$. Nusbaum et al. (2005) reported that the application of fertilizer in degraded soil is able to increase dry weight, basal diameter, and height for all plant species at the age of 6 months. The increase in height and basal diameter in fertilized M.gigantea seedlings are four times higher than those in unfertilized plants.

The result also showed that the accumulation of nutrients $\mathrm{N}, \mathrm{P}, \mathrm{K}, \mathrm{Ca}$, and $\mathrm{Mg}$ in $M$. gigantea was the highest at the P4 treatment (NPK $160 \mathrm{~g}$ fertilizer). The highest $\mathrm{N}$ accumulation was found in the leaves, followed by branches of wood and bark. The highest $\mathrm{P}$ nutrient was stored in the branch followed by leaves, wood, and bark. On the other hand, $\mathrm{K}, \mathrm{Ca}$, and $\mathrm{Mg}$ nutrients were more accumulated in branches, wood, leaves, and bark. The highest absorbed nutrient by M. gigantea from the soil was $\mathrm{K}$ with $676.20 \mathrm{~kg} . \mathrm{ha}-1$, followed by $\mathrm{N}$ with $344.01 \mathrm{~kg} . \mathrm{ha}-1$, $\mathrm{Ca}$ with $114.57, \mathrm{Mg}$ with $77.64 \mathrm{~kg}$.ha-1 and P with 43.04 kg.ha-1.

The content of $\mathrm{N}, \mathrm{P}, \mathrm{K}, \mathrm{Ca}$ and $\mathrm{Mg}$ in soil $(0-60 \mathrm{~cm})$ showed that plot $\mathrm{P} 4$ had the lowest nutrient content compared to Plots P0, P1, P2, and P3. Elements of K and P had a lower content than $\mathrm{N}, \mathrm{Ca}$ and $\mathrm{Mg}$ nutrients. It means that $M$. gigantea plant more easily absorbs nutrients in the soil for its growth. This plant is a fast-growing pioneer species that requires high levels of light within forest gaps of secondary (Davies et al. 1998; Romell et al. 2008). Fastgrowing tree species are generally considered to accumulate soil nutrients faster than slow-growing ones when multiple rotations are implemented (Cossalter and Pye-Smith 2003). Inagaki and Tange (2014) also reported that fast-growing Eucalyptus trees can accumulate more aboveground biomass than $\mathrm{N}_{2}$-fixing and other non- $\mathrm{N}_{2}$ fixing broadleaved trees while storing less aboveground $\mathrm{N}$. Furthermore, some Acacia and Eucalyptus trees can produce more aboveground biomass than other non- $\mathrm{N}_{2}-$ 
fixing broadleaved trees while using less Phosphorus. Montagnini (1998) reported that four years after planting, decrease in soil nutrients was apparent in pure plots of some of the fastest-growing species. On the other hand, some fast-growing tree species have strategies that allow them to grow on degraded soils. Montagnini (2000) reported that decreases in soil $\mathrm{P}, \mathrm{K}$ and $\mathrm{Ca}$ were apparent in pure plots of the fastest-growing species with the largest accumulation of nutrients in above-ground biomass, such as $J$. copaia and $V$. guatemalensis, five years after planting.

In this study, the highest accumulation of nutrients was also found at P4 plot. Nitrogen was accumulated at 344.01 kg.ha-1, $121 \%$ higher than non-fertilized control plants which accumulated only $155.9 \mathrm{~kg} . \mathrm{ha}-1$. The accumulation of phosphorus in the biomass of $M$. gigantea at $\mathrm{P} 4$ plot was 43.04 kg.ha-1, twice higher than the phosphorus content in control plot with 20.9 kg.ha-1. Potassium accumulation was $676.20 \mathrm{~kg}$.ha-1, three times higher than that at control plot (239.89 kg.ha-1). While for the calcium and magnesium nutrients, the accumulation of each nutrient in plant biomass was $114.57 \mathrm{~kg}$.ha-1 and $77.64 \mathrm{~kg}$.ha-1 at plot $\mathrm{P} 4$, twice higher compared to those at P0 control with $66.51 \mathrm{~kg} \cdot \mathrm{ha}-1$ and $36.1 \mathrm{~kg}$.ha-1. The addition of NPK fertilizer higher than $160 \mathrm{~g}$ significantly increased $\mathrm{N}, \mathrm{P}, \mathrm{K}$, $\mathrm{Ca}$ and $\mathrm{Mg}$ content of $M$. gigantea plant biomass. This nutrient has important role in photosynthesis. The finding of this study is in accordance with Cossalter and Pye-Smith (2003), which states that fast-growing tree species are generally considered to accumulate soil nutrients faster than slow-growing ones.

Potassium is the most accumulated nutrient in $M$. gigantea biomass with $676.20 \mathrm{~kg} \cdot \mathrm{ha}^{-1}$, consisting of $64 \%$ in stem and branch, and $36 \%$ in leaf and bark. On the other hand, the relative portion of $\mathrm{K}$ nutrients that were accumulated in $M$. gigantea stands was quite large, ranging between 18.83 and $55.82 \%$ (Figure 7) compared to other nutrients. This result shows that nutrient $\mathrm{K}$ is the most absorbed nutrient by M. gigantea. Hertemink (2001) reported that fast-growing species Piper aduncum also accumulated large amounts of biomass and nutrients, particularly K.

When M. gigantea plant is harvested at the age of five years with stems and branches taken out of the system, the greatest nutrient that will be reduced from the soil is potassium, followed by phosphorus, nitrogen, calcium, and magnesium. In the first cycle of harvesting $M$. gigantea, the soil will lose nutrients by $438 \mathrm{~kg}$.ha-1 (64\%), assuming that the leaves and barks were left on the site. Meckensen, (1999) and Meckensen et al. (2001) reported that nutrient content of fast-growing Eucalyptus deglupta in industrial plant forests in East Kalimantan $\left(100 \mathrm{~m}^{3} \log\right.$ and barks) was $\mathrm{N}$ with $44.4 \mathrm{~kg}$.ha-1, $\mathrm{P}$ with $2.3 \mathrm{~kg}$.ha- 1 and $\mathrm{K}$ with $125 \mathrm{~kg}$. ha-1. Uri et al. (2003) found that the amount of nutrients accumulated by 1-year-old grey alder in producing one tonne of biomass at an $\mathrm{N}: \mathrm{P}: \mathrm{K}$ ratio of 100:9:43. The uptake of nutrient K by $M$. gigantea is more abundant than Eucalyptus deglupta. Montagnini (2000) reported that in monoculture plantations, Vochysia guatemalensis had the greatest accumulation of $\mathrm{K}$ and $\mathrm{Ca}$. In V. guatemalensis plantation, stem harvest would remove less than $30 \%$ of $\mathrm{N}$ for $50 \%$ of total above-ground tree $\mathrm{Ca}$, $\mathrm{K}, \mathrm{Mg}$ and $\mathrm{P}$. Branches and foliage summed together contribute only 25 to $35 \%$ of total above-ground tree biomass, but they generally represent about $50 \%$ of aboveground tree nutrients. Mackensen and Foster (2000) reported that cost of fertilization is different across species. For example, fertilization costs for Eucalyptus deglupta are generally higher than Acacia mangium. Alriksson and Eriksson (1998) suggested that the choice of tree species harvest and stem-wood harvest is when they reach similar rates of stem-wood biomass production. On the other hand, Montagnini (2000) reported that continued sampling will be needed to assess the long term effects of plantation treatments on soil chemistry, especially near the end of the rotation

\section{ACKNOWLEDGEMENTS}

We acknowledge Faculty of Forestry, Mulawarman University, Indonesia for providing permission to conduct the fieldwork in the research forest. This work was financially supported by the Grant of Mulawarman University Research of Excellent Program (UNMUL PDUPT) for DS, RK and RA, provided by the Directorate General of Research and Development, the Ministry of Research, Technology, and Higher Education of Indonesia.

\section{REFERENCES}

Amirta R, Mukhdlor A, Mujiasih D, Septia E, Supriadi, Susanto D. 2016. Suitability and availability analysis of tropical forest wood species for ethanol production: a case study in East Kalimantan. Biodiversitas 17 (2): 544-552. DOI: 10.13057/biodiv/d170225

Alriksson A, HM Eriksson. 1998. Variations in mineral nutrient and C distribution in the soil and vegetation compartments of five temperate tree species in NE Sweden. Forest Ecology and Management 108 (3): 261-273. DOI: 10.1016/S0378-1127(98)00230-8

Bentos TV, Mesquita RCG, Williamson GB. 2008. Reproductive phenology of Central Amazon pioneer trees. J Trop Conserv Sci 1 (3): 186-203. DOI: 10.1177/194008290800100303

Cossalter and Pye-Smith. 2003. Fast-Wood Forestry Myths and Realities. Center for International Forestry Research, Jakarta. [Indonesian]

Davies SJ, Ashton PS. 1999. Phenology and fecundity in 11 sympatric pioneer species of Macaranga (Euphorbiaceae) in Borneo. Amer J Bot 86 (12): 1786-1795. DOI: $10.2307 / 2656675$

Davies SJ. 1998. Photosynthesis of nine pioneers Macaranga species from Borneo in relation to life history. Ecology 79:2292-2308. DOI: $10.2307 / 176823$

Hertemink AF. 2001. Biomass and nutrient accumulation of Piper aduncum and Imperata cylindrica fallows in the humid lowlands of Papua New Guinea. Forest Ecology and Management 144 (1-3):1932. DOI: 10.1016/S0378-1127(00)00655-1

Inagaki M, Tange T. 2014. Nutrient accumulation in aboveground biomass of planted tropical trees: a meta-analysis. J Soil Sci Plant Nutr 60 (4): 598-608. DOI: 10.1080/00380768.2014.929025

Lawrence D. 2001. Nitrogen and phosphorus enhance growth and luxury consumption of four secondary forest tree species in Borneo. Journal of Tropical Ecology 17:859-869. DOI: 10.1017/S0266467401001638

Meckensen J.1999. Nutrient management for industrial tree plantation. A practical guidance towards integrated nutrient management. Deutsche Gesellschaft fur Technische Zusammenarbeit (GTZ) GmbH Postfach 5180. D-65726 Eschborn.

Mackensen J, H. Foster. 2000. Cost-analysis for sustainable nutrient management of fast growing tree plantations in East-Kalimantan, 
Indonesia.For Ecol Manag 131 (1-3): 239-253. DOI: 10.1016/S03781127(99)00217-0

Meckensen J, Ruhiyat D, Folster H. 2001. Volume-based nutrient content of Acacia mangium, Eucalyptus deglupta and Paraserianthes falcataria in industrial tree plantations in East Kalimantan, Indonesia. J Trop For Sci 13:512-526.

Mindawati N, Bogidarmanti R, Nuroniah HS, Kosassih AS, Suhartati, Rahmayanti S, Junaidi A, Rachmad E, Rochmayanto Y. 2010 Synthesis silviculture research of species alternatives for wood pulp production. Research and Development Center for Increasing Forest Productivity, Bogor, Indonesia.

Montagnini F. 1998. Evaluating the Role of Plantations as Carbon Sinks: An Example of an Integrative Approach from the Humid Tropics. Environ Manag 22 (3): 459-470. DOI: 10.1007/s002679900119

Montagnini F. 2000. Accumulation in above-ground biomass and soi storage of mineral nutrients in pure and mixed plantations in a humid tropical lowland. For Ecol Manag 134 (1-3): 257-270. DOI 10.1016/S0378-1127(99)00262-5

Nussbaum R, Anderson J, Spenser T. 1995.Factors limiting growth of indigenous tree seedlings planted on degraded rain forest soil in Sabah, Malaysia. For Ecol Manag 74: 149-159. DOI: 10.1016/03781127(94)03496-J

Romell EG, Hallsby G, Karlsson A, Garcia C. 2008. Artificial canopy gaps in a Macaranga spp. dominated secondary tropical rain foresteffects on survival and above ground increment of four under-planted dipterocarp species. Forest Ecology and Management 255: 14521460. DOI: $10.1016 /$ j.foreco.2007.11.003
Ruhiyat D. 1996. Estimasi Biomassa Tegakan Hutan Hujan Tropis di Kalimantan Timur. Rimba Kalimantan 1 (1): 42-57. [Indonesian]

Slik FJW, Bernard CS, Van Beek M, Breman FC, Eichhorn KAO. 2008 Tree diversity, composition, forest structure and aboveground biomass dynamics after single and repeated fire in a Bornean rain forest. Oecologia. DOI 10.1007/s0042-008-1163-2.

Susanto D, Ruhiyat D, Sutisna M, Amirta R. 2016a. Flowering, fruiting, seed germination and seedling growth of Macaranga gigantea. Biodiversitas 17 (1): 192-199. DOI: 10.13057/biodiv/d170128

Susanto D, Ruhiyat D, Sutisna M, Amirta R. 2016b. Soil and leaf nutrient status on growth of Macaranga gigantea in secondary forest after shifting cultivation in East Kalimantan, Indonesia. Biodiversitas 17 (2): 409-416. DOI: $10.13057 /$ biodiv/d170202.

Susanto D, Hayatudin, Setiawan A, Purnomo H, Ruhiyat D, Amirta R. 2017a. Characterizing nutrient status and growth of Macaranga gigantea in tropical rainforest gaps after selective logging in East Kalimantan, Indonesia. Biodiversitas. DOI: 10.13057/biodiv/d180318

Susanto D, Mulyati S, Purnomo H, Ruhiyat D, Amirta R. 2017b. Growth, biomass production and nutrient accumulation of Macaranga gigantea in response to NPK fertilizer application. Nusantara Biosci 9 (3): 330337. DOI: $10.13057 /$ nusbiosci/n090315

Suita E, Nurhasybi. 2009. Seed and plant propagation collection pioneers type Macaranga sp. for forest and land rehabilitation. Info Benih 13 (1): 170-175. [Indonesian]

Uri V, Tullus H, Lohmus K. 2003. Nutrient allocation, accumulation and above-ground biomass in Grey Alder and Hybrid Alder plantations. Silva Fennica 37 (3): 301-311. DOI: 10.14214/sf.490 